\title{
Sacred groves and sacred plants of the Dimasas of North Cachar Hills of Northeast India
}

\author{
Pramod Medhi ${ }^{1 \star}$ and Sachin Kumar Borthakur ${ }^{2}$ \\ ${ }^{1}$ Department of Botany, Haflong Government College, Haflong-788819, Assam, India. \\ ${ }^{2}$ Department of Botany, Gauhati University, Guwahati-781014, Assam, India.
}

Accepted 13 November, 2012

\begin{abstract}
The present paper deals with the rediscovery of 12 sacred groves, known as Dikhos, preserved by the Dimasa community of North Cachar Hills district recently renamed as Dima Hasao district of Assam, India. Located strategically, these sacred groves provide several important ecological services to the people of the district. In addition to the sacred groves the plants considered to be sacred by them are also included. Out of the 34 plant species considered to be sacred by the Dimasas, 13 species are related to worshiping, 21 species involved in naming of areas/villages and eight species are associated with the naming of the Clans (Sengphong that is, male clans and Jaddi/Zaluk that is, female clans). However, some of the species/rice landraces have been associated with more than one ways. The Dimasas, also known as Dimasa Kacharies, constitute the largest ethnic group in North Cachar Hills and linguistically belongs to the Tibeto-Burman group.
\end{abstract}

Key words: Phytoresources, sacred groves, sacred plants, Dimasas, North Cachar Hills, India.

\section{INTRODUCTION}

Traditional ecological knowledge is concerned with the dynamic relationships between traditional societies and landscapes, ecosystems, populations and between individual species. This knowledge system has significance in three broad ways: economical, ecological/social and ethical. The ethical aspect deals with the cultural, spiritual and religious belief systems centered around the concept of the sacred species, sacred groves and sacred landscapes, etc. (Ramakrisnan, 2001). North Cachar (N. C.) Hills district of Assam, recently renamed as Dima Hasao district, is one of the two hill district of Assam in Northeastern India. The district is located in between $25^{\circ} 58^{\prime}$ to $25^{\circ} 47^{\prime} \mathrm{N}$ latitudes and $92^{\circ} 27^{\prime}$ to $93^{\circ} 43^{\prime}$ ' E longitudes with an area of $4,890 \mathrm{sq}$. $\mathrm{km}$. Topographically, the altitude of the district ranges from 140 to $1866 \mathrm{~m}$ above msl. The district has a total population of 2,13,529 with a density of 44 per sq. km. (Anonymous, 2005). More than $70 \%$ of the population of the district belongs to different ethnic groups viz.: Dimasas, Jeme Nagas, Hmars, Kukis, Karbis,

\footnotetext{
${ }^{*}$ Corresponding author. E-mail: pramodmedhi@yahoo.com.
}

Biates, Jaintias (Pnar), Hrangkhawls, Khelmas, Vaipheis, etc. Acculturation and other obvious reasons over the time, it has become increasingly difficult to identify and locate some of the sacred groves of the Dimasas. With this backdrop, an attempt has been made to rediscover and document those sacred groves and also the plants revered as sacred by the Dimasas inhabiting in the district.

\section{THE DIMASAS}

The Dimasas or Dimasa Kacharies, constitute the largest ethnic group in N. C. Hills district. Linguistically, they belong to the Tibeto- Burman group. The term 'Dimasa' literally means the son of a big river; $\mathrm{Di}$ means water, $\mathrm{Ma}$ means big and Sa means son. As the Brahmaputra is the biggest and longest river in Assam, it may be presumed that the Dimasas considered themselves to be the descendants of the river Brahmaputra (Barpujari, 1997). The total population of the Dimasas in N. C. Hills district is 64,881 and they constitute $32.90 \%$ of total population of the district (Anonymous, 2005). 


\section{Social life}

The Dimasas follow the patriarchal system. However, parallel clans of both male and female are also recognised in the Dimasa society and as such there are 40 male clans or Sengphong and 42 female clans or Jaddi / Zaluk. Both the clans are exogamous and marriage within the same clan is a social taboo (Guha 1912). The paternal property is inherited by sons only after the death of the father and the maternal property is inherited by the daughters only (Nunisa, 2006).

\section{Religious life}

The Dimasas believe in Hinduism with an admixture of animism. They believe that different parts of their habitations are reign by six ancestral gods or Madai viz., Sibrai, Alu Raja, Naikhu Raja, Wa Raja, Ganiyang- Braiyung and Hamiadao and these gods have their full control under their jurisdiction. Thus the concept of area-god has developed amongst them. The area-gods are considered to have their adobes in different forest patches, known as Dikhos (sacred groves), of the Dimasa land. The shrines of these gods are not housed in any temple but installed and worshiped inside the Dikhos. In the past there were 12 Dikhos and the Dimasas believed that gods and goddesses residing in a particular Dikho protect the people of that area and control their destiny. These Dikhos are very important as these forest patches are conserved through the community participation for ethical reasons (Lalsim, 2005).

A number of publications on different aspects of sacred groves of different parts of northeast India have appeared during the last few decades and these include, ethno medicinal plants in the sacred groves of Manipur (Ashalata et al., 2005), plants in religio-cultural beliefs of the Tai Khamtis of Assam, India (Gogoi and Borthakur 1991), tribal man in the humid tropics of the north-east India (Ramakrisnan, 1985), socio-cultural studies of the sacred groves at Cherrapunjee and adjoining areas in north-eastern India (Ramakrisnan and Kiewtam, 1989), ethno botanical study on indigenous people and forests from Nagaland, northeast India (Rao, 1996) and relevance of ethno forestry in Arunachal Pradesh, India (Shukla and Haridarshan 1996).

Publications from other parts of the Indian subcontinent includes traditional worshiping plants (Bhatla et al., 1984), tribal dependence and tradition on forests (Deeney and Fernandes, 1992), role of tribals in preservation of sacred forests (Godbole, 1996), tribal clans in central India and their role in conservation (Jain, 1988), ethnobotanical aspects of tropical ecosystems (Jain, 1989), socio-cultural and environmental studies on religious forest patches among Mahadeo Koli tribal localities from south India (Kulkarni et al., 1996), cultural heritage of sacred groves (Nipunage et al., 1992), conserving the sacred forest for biodiversity management
(Ramakrisnan et al., 1998), sacred groves for in-situ conservation (Vartak, 1996), studies on the role of believes and folklores on sacred groves along Maharastra and Goa (Vartak and Gadgil, 1997) and treasure trove of medicinal plants in the sacred groves of tribal areas of Western Ghats (Vartak et al., 1987).

Again, indigenous views of land and environment (Davis, 1993), sacred mountain forests and biodiversity (Ramakrisnan, 2000a), ethnobotanical value and conservation of sacred groves of the Kpaamende in Sierra Leone (Lebbie and Guries, 1995), sacred forests in Sierra Nevada de Santa Marta Columbia (RodriguezNavarro, 2000) and linking protected area management with local people communities (Wells and Brandon 1992), etc. publications from other parts of the world are taken into account as references.

\section{MATERIALS AND METHODS}

An extensive field work was carried out during 2007 to 2009 to study encompassing on the documentation plant resources and traditional knowledge pertaining to these resources from N. C. Hills of Assam. Plant samples bearing a total of 861 field numbers were collected and their traditional uses by the ethnic people of the area were recorded. Identification of the locations and working out of the area cover of the sacred groves which became indistinguishable from the surrounding forests and also documentation of the plants considered to be sacred by the Dimasas was also part of the study.

The collected plant materials were made into herbarium specimens following standard herbarium techniques suggested by Jain and Rao (1977). The specimens were identified with the help of local floras (Chauhan et al., 1996; Deb, 1981; Kanjilal et al., 1934 to 1940 , Singh et al., 2002, Rowntree, 1953) and/or with the help of herbarium specimens deposited in the Kanjilal Herbarium, Botanical Survey of India, Shillong (ASSAM). The specimens on which this study is based have been deposited in the Herbarium of Botany Department, Gauhati University (GUBH).

Germplasms of the rice landraces used in naming the clan names were collected and their passport data have been prepared following the standard procedure/guidelines (Sharma, 2000). All the collected rice germplasm accessions were already submitted to NBPGR Regional Station, Meghalaya-793103, India for conservation. Information regarding the field/collection number, date and place, botanical name, vernacular name(s), biological status (whether wild or cultivated) and traditional uses of the recorded plant species considered as sacred by the Dimasas were also provided.

\section{RESULTS}

The present communication is an outcome of a comprehensive study on plant resources and traditional knowledge pertaining to these resources of N. C. Hills of Assam which includes the brief descriptions of 12 Dikhos (sacred groves) of the Dimasa community in the district and a total of 34 species considered to be sacred by them were been recorded. Out of which, 13 species are related to worshiping, 21 species involved in naming of areas/villages and eight species are associated with the naming of the clans. However, three species viz., Areca 
catechu, Dendrocalamus giganteus and Melocanna baccifera are associated both with worshipping and naming of the areas/villages. Similarly, Artocarpus chama is involved both in the naming a village and a male clan. Emblica officinalis is associated with worshipping, naming of a village and a female clan. Oryza sativa is associated with the naming of three villages, one male clan and 27 female clans.

\section{Sacred groves of the Dimasas}

The Sacred Groves have been playing an important role in conservation of biodiversity as these forest areas are experiencing least or without human interferences like Jhum cultivation, cutting of trees for fuel and/or for timber, etc. Therefore, these forests are usually rich in biodiversity which have been conserved through community participation.

In Dimasa society an administrative hierarchy has been followed from highest ranked priest to the common people of different clans. For each of the 12 Dikhos there is one priest or Jonthai to perform and look after the religious rites of the Dikho. The authority of a Jonthai is undisputed and he performs his duties as per the instruction of a head priest or Jonthaima of all the Dikhos. There is also a principal priest or chief priest, known as Gisia, at the top of the hierarchy. The person selected for Jonthaiship is baptised by the Gisia by sprinkling holy water or Dithar. The religious hierarchal structure among the Dimasas is as follows:

GISIA (Son of the God) $\rightarrow$ JONTHAIMA (Head priest) $\rightarrow$ BAROWA (Assistant priest) $\rightarrow$ JONTHAI (Sub-clan wise12 Jonthais) $\rightarrow$ GENERAL VILLAGE PEOPLE.

The following are the brief description of the 12 sacred groves of the Dimasas from North Cachar Hills District of Assam, India with their locations shown in the map (Figure 1).

i) Aludikho: There are two Aludikhos maintained by the Dimasas; one at Mahurbra village near Dihangi at the confluence of river Mahur and Diyung and the other one at Thongikhrow/Wajaw village in a remote place of Maibang area. The extents of these two Dikhos are 2.46 and 2.28 acres, respectively. For the convenience of the people, worshiping their own clan gods in nearby Dikho is the reason behind the maintenance of two similar Dikhos in two different parts of the district.

ii) Longmailaidikho: Located at Moti village of the Mahur area and has an area of 2.72 acres.

iii) Longmailumdikho: Located at Dijowahapa village of Mahur area with an area of 2.16 acres.

iv) Manjadikho: Located at Mailu village in Langting area and its extent is 2.83 acres.

v) Damadidikho/Riaodikho: Located in between Sampha- ridisa and Gaijon/Nogdi Daulagupu village, at the confluence of river Hagong and Diyung, that is, Abungbra. It is the biggest of all the 12 Dikhos and spread over area 3.67 acres. The five clan gods viz., Naikuraja, Nobaraia, Waraja, Shivarai and Kampadi are worshiped here (Figures 2A, B and C).

vi) Hamridikho: Located at Palaipa/Daudungkhor village in Thaijuwari area at the confluence of river Langting and Diyung. This Dikho covers an area of 1.86 acres.

vii) Misimdikho: Located at Gerem basti village in Mahur area has an area of 1.71 acres.

viii) Baiglaidikho/Baigiadikho: Located at a remote village Bongkhai in Khepre area near Nagaland border with an area of 2.82 acres.

ix) Waibradaikho: Located at Hajageder village of Langting area and is considered as Daikhongmahi Deng (means Purest Dikho) among all the Dikhos of the Dimasas. This Dikho has an area of 2.65 acres and only recently rediscovered it by the community after remaining unknown for quite a long time.

$x)$ Mongrangdikho/Semkhordikho: Located at the Semkhor village considered to be the original Dikho of the Semsas, a male clan of the Dimasas with an area of 2.89 acres.

xi) Mongrangdikho: Located at Delen bathari near Banjikhalu village of Maibang area $(12 \mathrm{kms}$.from Maibang town) and at the confluence of river Dugu and Delen that is, Dugubra.This Dikho has an area of 1.85 acres and is for the Semsas dwelling outside the Semkhor village for worshiping their own clan god.

xii) Ronchandidikho (Bamin): During the Kachari reign this Dikho was originally located at Dajdi village in eastern Maibang area (side of Dhansiri River), but when the capital of the Kachari Kingdom was shifted to Khaspur (now in Cachar District of Assam), a new Dikho was demarcated there. However, nowadays, at Khaspur only the monuments are there without any Gisia and Jonthais and all the traditional rites are performed at the Dikho located at Dajdi village .This Dikho has an area of 3.10 acres.

\section{Sacred plants of the Dimasas}

The traditional life style of the Dimasas of N.C. Hills has been strongly influenced by the natural resources available in and around their habitations. Apart from the food and other material needs, utilization and management of the plant resources have been closely associated with culture and tradition of the Dimasas. The identity of an area/village is often associated with plant resource either available in the area/village or importance to the people.

Accordingly, the area/village has been named after the plant resource. All the plants used for worshiping, naming of an area/village and clans are held sacred by the Dimasas. 


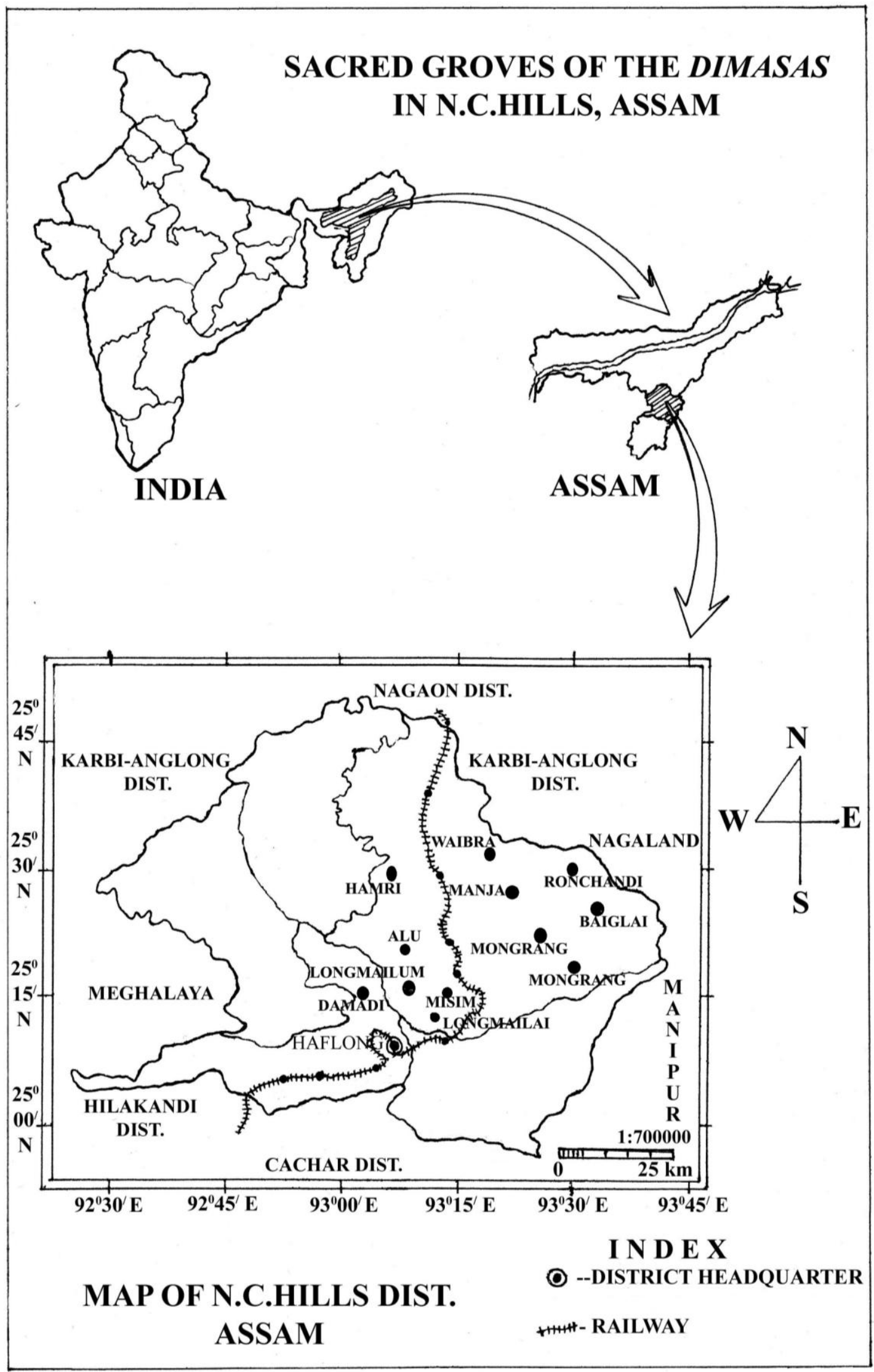

Figure 1. Map of N. C. Hills showing Dikhos of the Dimasas (Location not to the scale). 


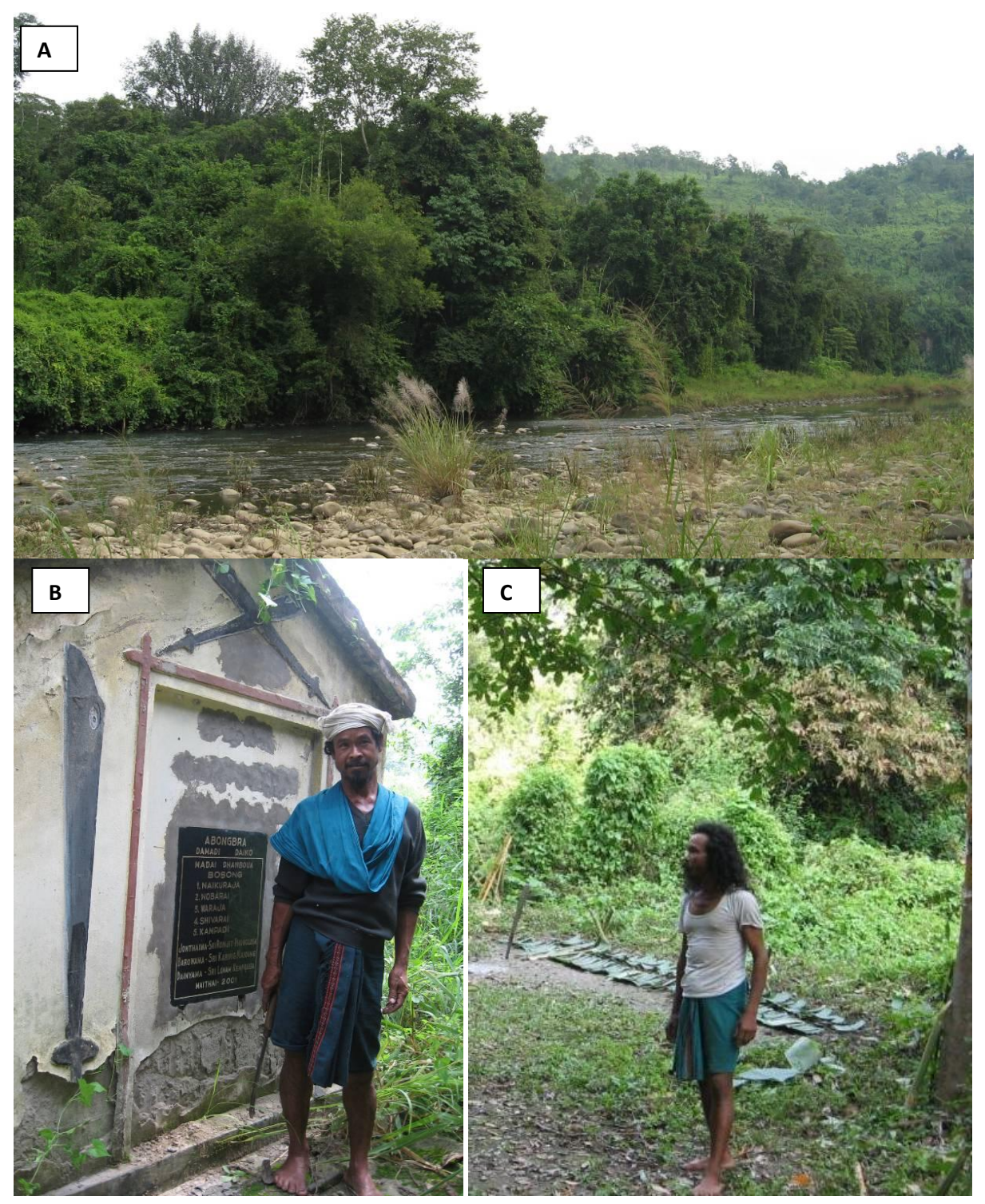

Figure 2. A) The largest sacred grove Damadidikho. B) Local village men showing the name of the gods worshiped in Damadidikho. C) Jonthai, the traditional priest using Melocanna buccifera culm and Musa sp. leaf in worshipping.

\section{Sacred plant used for worshiping}

Present study reveals a total of 13 plant species considered as sacred and associated with worshiping by the Dimasas of the area are enumerated (Table 1).

\section{Plant used for naming of the areas/villages and clans}

Naming of the areas/villages derived from plant(s) name: Names of 23 areas/villages which have been derived from plant names in Dimasa dialect of 21 species are recorded from the study area (Table 2). However, three villages viz., Maibang, Mailu and Mailong disha were derived from the names of three different landraces of rice (Oryza sativa).

Naming of clans derived from plant(s) name: Out of the existing 82 male and female clans of the Dimasas, a total of 34 clans have been named on the basis of the names of the plants in Dimasa dialect. A total of seven plant species were recorded to be associated with the naming of the clans.

a) The names of five male clans that is, Sengphong were based on the names of one landrace of Oryza sativa and four other plant species which has been provided in the Table 3. 
Table 1. Sacred plants associated with worshiping of the Dimasas.

\begin{tabular}{|c|c|c|c|}
\hline $\begin{array}{l}\text { Botanical name, family; } \\
\text { collection no.; date; locality }\end{array}$ & Vernacular name & $\begin{array}{l}\text { Biological } \\
\text { status }\end{array}$ & Use \\
\hline $\begin{array}{l}\text { Abroma augusta L. } \\
\text { [Sterculiaceae]; PM-779; 07-12- } \\
\text { 2009; Sampharidisha }\end{array}$ & $\begin{array}{l}\text { Bon naga (DI), Dieng- } \\
\text { tyrkhum (PN) }\end{array}$ & WI & $\begin{array}{l}\text { A twig is used during sacrifice of buffalos in } \\
\text { Maimuhtarba ceremony. }\end{array}$ \\
\hline $\begin{array}{l}\text { Areca catechu L. [Arecaceae]; } \\
\text { PM-780; 12-01-2009; Dibarai }\end{array}$ & $\begin{array}{l}\text { Gowai (DI), Kuvara } \\
\text { (HM), Tegut chi (ZE) }\end{array}$ & $\mathrm{Cv}$ & $\begin{array}{l}\text { Pair of fresh fruits and Piper wallichii (Mithibon- } \\
\text { DI) leaves is indispensable item in all religious } \\
\text { ceremonies. }\end{array}$ \\
\hline $\begin{array}{l}\text { Bambusa tulda Roxb. [Poaceae]; } \\
\text { PM-781; 07-12-2009; } \\
\text { Sampharidisha }\end{array}$ & $\begin{array}{l}\text { Washi (DI), Hebeu } \\
\text { (ZE) }\end{array}$ & WI & Leaves and culms are used in worshiping. \\
\hline $\begin{array}{l}\text { Celosia cristata L. } \\
\text { [Amaranthaceae]; PM-783; 07- } \\
\text { 12-2009; Sampharidisha }\end{array}$ & Khemsa gajao (DI) & $\mathrm{Cv}$ & $\begin{array}{l}\text { Twig with inflorescences used in a religious } \\
\text { ceremony called Dakinsa. }\end{array}$ \\
\hline $\begin{array}{l}\text { Dendrocalamus giganteus Munro. } \\
\text { [Poaceae]; PM-784; 20-12-2007; } \\
\text { Boro Waphu }\end{array}$ & Waphu (DI) & WI & Leaves and culms are used in worshiping. \\
\hline $\begin{array}{l}\text { Emblica officinalis Gaertn. } \\
\text { [Euphorbiaceae]; PM-785; 22-09- } \\
\text { 2008; Gurubari }\end{array}$ & $\begin{array}{l}\text { Hamlaithai (DI), Gam } \\
\text { so-lu (MI), Jauka chi } \\
\text { (ZE) }\end{array}$ & SWI & $\begin{array}{l}\text { The tree is worshiped by the father of a sick } \\
\text { baby for early recovery and the parent } \\
\text { concerned refrain from cutting the plant in rest of } \\
\text { their lifetime. }\end{array}$ \\
\hline $\begin{array}{l}\text { Melocanna baccifera (Roxb.) } \\
\text { Kurz. syn. Melocanna } \\
\text { bambusoides Trin. [Poaceae]; } \\
\text { PM-787; 21-12-2007; Longma-III }\end{array}$ & Wa-thi (DI) & WI & $\begin{array}{l}\text { i. Culms are used for water purification rituals } \\
\text { especially during Misengba ceremony. } \\
\text { ii. Offering of rice beer (Judima) in cups made } \\
\text { from the culms to the deities in various religious } \\
\text { ceremonies is a common practice. }\end{array}$ \\
\hline $\begin{array}{l}\text { Musa velutina Wendl. } \\
\text { [Musaceae]; PM-788; 21-12- } \\
\text { 2007; Longma-III }\end{array}$ & $\begin{array}{l}\text { Thailik/Laishrimdi (DI), } \\
\text { Gam Nachang vui } \\
\text { (HM/MI), Gumjui (ZE) }\end{array}$ & WI & $\begin{array}{l}\text { Leaves and leaf sheaths are used in religious } \\
\text { ceremonies as platters. }\end{array}$ \\
\hline $\begin{array}{l}\text { Piper wallichii (Miq) Hand. Mazz. } \\
\text { [Piperaceae]; PM-789; 12-01- } \\
\text { 2009; Dibarai }\end{array}$ & $\begin{array}{l}\text { Mithibon }(\mathrm{DI}) \text {, Kobi } \\
\text { rang }(\mathrm{HR})\end{array}$ & WI & $\begin{array}{l}\text { Pair of both fresh leaves and Areca catechu } \\
\text { fruits (Gowai-DI) is indispensable item in all the } \\
\text { religious ceremonies. }\end{array}$ \\
\hline $\begin{array}{l}\text { Smilax perfoliata BI. } \\
\text { [Smilacaceae]; PM-790; 21-12- } \\
\text { 2007; Longma-III }\end{array}$ & $\begin{array}{l}\text { Shidigubru (DI), Jun } \\
\text { se-pi (HR), }\end{array}$ & WI & $\begin{array}{l}\text { It is believed that children get cured of bed- } \\
\text { wetting if lunch and dinner are served using the } \\
\text { fresh leaves of this plant as plate. }\end{array}$ \\
\hline
\end{tabular}


Table 1. Continued

\begin{tabular}{ll}
\hline $\begin{array}{l}\text { Streblus asper Lour. [Moraceae]; } \\
\begin{array}{l}\text { PM-791; 07-12-2009; } \\
\text { Sampharidisha }\end{array} \quad \text { Khande (DI) }\end{array} \quad$ WI $\quad \begin{array}{l}\text { The tree is believed to be the abode of the evil } \\
\text { spirits. When a person remains sick for long } \\
\text { time the village priest (Jonthai) worships below } \\
\text { the tree for his early recovery. }\end{array}$ \\
\hline
\end{tabular}

Table 2. Naming of the Dimasa areas/ villages derived from plant(s) name.

\begin{tabular}{|c|c|c|c|}
\hline Collection no. & Name of village & Vernacular names of the plants & Botanical name \\
\hline PM-792 & Boro waphu & Wa-Bamboo; guphu-white & Dendrocalamus giganteus Munro. [Poaceae] \\
\hline PM-793 & Boro washilling & Wa-Bamboo; shilling-garden & Dendrocalamus hamiltonii Nees et Arn. ex Munro [Poaceae] \\
\hline PM-794 & Choto waphu & Wa-Bamboo; guphu-white & Bambusa cacharensis R. Mazumdar [Poaceae] \\
\hline PM-795 & Choto washilling & Wa-Bamboo; shilling-garden & Dendrocalamus hookeri Munro [Poaceae] \\
\hline PM-796 & Dihamlai & Di-water; Hamlai-Emli & Emblica officinalis Gaertn. [Euphorbiaceae] \\
\hline PM-797 & Galaphang & Gala-Bitter gourd; Phang-Plant & Momordica charantia var. muricata (Willd.) H.L. Chakravarty [Cucurbitaceae] \\
\hline PM-798 & Gowaidisha & Gowai-Areca nut; Disha-stream & Areca catechu L. [Arecaceae] \\
\hline PM-799 & Gurubari & Guru-Sugarcane; Bari-cultivation field & Saccharum officinarum L. [Poaceae] \\
\hline PM-800 & Jaramdisa & Jaram-Artocarpus plant; Disha-stream & Artocarpus chama Buch.-Ham. [Moraceae] \\
\hline PM-801 & Maibang & Mai- paddy; bang-large quantity & Oryza sativa L. [Poaceae] \\
\hline PM-802 & Mailong disha & Mai- paddy; Disha-stream & Oryza sativa L. [Poaceae] \\
\hline PM-803 & Mailu & Mai- paddy & Oryza sativa L. [Poaceae] \\
\hline PM-804 & Michikur & Michi-Finger millet & Setaria italica (L.) Beauv. [Poaceae] \\
\hline PM-805 & Muolhoi & Muol-Lichi plant; hoi-garden (In Hmar language) & Litchi chinensis Sonner. [Sapindaceae] \\
\hline PM-806 & Railing-hadi & Rai-Cane; Hadi-wet land paddy & Daemonorops jenkinsianus (Griff.) Mart. [Arecaceae] \\
\hline PM-807 & Sampharidisha & Samphariphang-Michelia sp. plant ; Disha-stream & Michelia champaca L. [Magnoliaceae] \\
\hline PM-808 & Thaijuphangwari & Thaiju-Mango; Wari-lake & Mangifera indica L. [Anacardiaceae] \\
\hline PM-809 & Tentriphang-hading & Tentriphang-Tamarind plant; Hading- Hill & Tamarindus indica L. [Caesalpiniaceae] \\
\hline PM-810 & Wadreng disha & Wadreng-a bamboo species; Disha-stream & Phyllostachys mannii Gamble [Poaceae] \\
\hline PM-811 & Wajao & Wa-Bamboo; Gajao-Red & Dinochloa maclellandii (Munro) Kurz [Poaceae] \\
\hline PM-812 & Washu bil & Wa-Bamboo; Shu-thorn & Chimonobambusa callosa (Munro) Nakai [Poaceae] \\
\hline PM-813 & Wathi disha & Wathi-Bamboo & Melocanna baccifera (Roxb.) Kurz. syn. Melocanna bambusoides Trin. [Poaceae] \\
\hline PM-814 & Wayung disha & Wayung-Bamboo; Disha-stream & Melocalamus compactiflorus (Kurz) Benth. [Poaceae] \\
\hline
\end{tabular}


Table 3. Plants associated with the naming of the Dimasa male clans.

\begin{tabular}{cclll}
\hline $\begin{array}{c}\text { Clan } \\
\text { no. }\end{array}$ & Coll. no. & Name of male clan & Vernacular names of the plants & Botanical name \\
\hline 6. & PM-815 & Mitherphangsa & Mither-the plant; Phang-plant; Sa- Son & $\begin{array}{l}\text { Actephila excelsa Mull.-Arg. } \\
\text { [Euphorbiaceae] }\end{array}$ \\
32. & PM-816 & Maibangsa & Mai -Rice; Bang-large quantity; Sa -son & Oryza sativa L. [Poaceae] \\
34. & PM-817 & Sarongphangsa & $\begin{array}{l}\text { Sarong- the plant; homa-spine on the } \\
\text { fruit epicarp; phang-tree; Sa-son }\end{array}$ & $\begin{array}{l}\text { Castanopsis indicus (Roxb.) A. DC. } \\
\text { [Fagaceae] }\end{array}$ \\
38. & PM-818 & Jarambosa & Jaram -the plant and Sa-son & $\begin{array}{l}\text { Artocarpus chama Buch. Ham. } \\
\text { [Moraceae] }\end{array}$ \\
39. & PM-819 & Lafthaisa & Lafthai-the plant; Sa-son & $\begin{array}{l}\text { Lagernaria siceraria (Molina) } \\
\text { Standley [Cucurbitaceae] }\end{array}$ \\
\hline
\end{tabular}

b). Altogether the names of the 29 female clans that is, Jaddi/Zaluk have been derived either from the specific plant or plant product deposited to the treasury of the king in the past. Except Hamlai gimindi and Kimbersi, rests of the 27 names of female clans were derived from the names in Dimasa dialect of different landraces Oryza sativa. Often the same clan name has different matrilineal origin. Different rice landraces having different local names in Dimasa dialect used for naming the clans have been provided here (Table 4).

\section{Abbreviations used for indicating}

a) Ethnic communities: (DI)-Dimasa, (HM)-Hmar, (HR)Hrangkhol, (MI)-Mizo, (PN)-Pnar (Jaintia) and (ZE)-Zeme Naga.

b) Biological status: Cv-cultivar, SWI-semi-wild and WIwild.

\section{DISCUSSION}

The present study reveals that the recorded plants are related to the socio-cultural life of the Dimasas of North Cachar Hills of Northeast India as these plants are associated to the traditional worshipping, naming of areas/villages as well as the male and female clans. Considering these plant resources as sacred plants and protecting them in their locality by the Dimasas are contributing towards the biodiversity conservation along with the ethical aspects of the community.

The presence of a number of primeval forest patches or sacred groves preserved by the Dimasas in North Cachar Hills district of Assam through various religious beliefs and social sanctions attached to them is significant as maintenance is known so far from the state of Meghalaya in northeastern India (Hajra, 1975; Khiewtam and Ramakrishnan, 1989; Tiwari et al., 1995,1998).

Sacred groves represent the dense vegetation of an area, and in most cases the vegetation formed a sharp boundary with the adjacent degraded forests. From the locations of the sacred groves maintained by the Dimasas at the catchment areas of major rivers or rivulet or at the point of origin of perennial streams, it is evident that the sacred groves provide such important ecosystem services as conserving soil, protecting water sources and catchment areas and helping to maintain downstream water quality.

The studies of sacred groves in other parts of India show that such forests are repository of biodiversity, safe sites for reproduction of a variety of floral and faunal resources, and last refuge of a number of rare, endangered and threatened plants (Bor, 1942a, 1942b; Haridasan and Rao, 1985, 1987; Darlong, 1995; Vartak and Gadgil, 1997).

Considering the conversational, cultural and aesthetic importance, further studies on the sacred groves of the Dimasas have been taken up since 2009 to assess the biodiversity status and value. The intimate association of the Dimasas with the nature is not only confined to the use of natural resources and conservation of forests through belief alone but also provide sanctions to a number of individual plants by incorporating in their religious rites, social customs or even as part of their social structures as names of villages or names of clans.

\section{ACKNOWLEDGEMENTS}

Authors are thankful to the ethnic people of N. C. Hills, other local informants and specially the Dimasa community who are conserving the sacred groves in the area. 
Table 4. Plants associated with the naming of the Dimasa female clans:

\begin{tabular}{|c|c|c|c|c|}
\hline Clan no. & Collection no.; IC no. & Name of female clans & Vernacular names/landraces of plants & Botanical name \\
\hline 2. & PM-820 ; IC no.560793 & $\begin{array}{l}\text { Banglaima gedeba } \\
\text { fashaidi }\end{array}$ & $\begin{array}{l}\text { Banglaima-A Jhum cultivar rice landrace Banglaisha; } \\
\text { Gedeba-large. }\end{array}$ & Oryza sativa L. [Poaceae] \\
\hline 4. & PM-821; IC no. 560767 & Mairong fashidi kasiba & $\begin{array}{l}\text { Mairong-Rice kernel of Maijau-di-gajao (Red husk } \\
\text { colour); kasiba-small. }\end{array}$ & Oryza sativa L. [Poaceae] \\
\hline 5. & PM-822; IC no.560797 & $\begin{array}{l}\text { Mairong gedeba-sam } \\
\text { desagao }\end{array}$ & $\begin{array}{l}\text { Mairong-Rice kernel of Maiju-walao-gidiba (with sticky } \\
\text { and mild aroma); Gedeba-large; desagao-leader. }\end{array}$ & Oryza sativa L. [Poaceae] \\
\hline 7. & PM-823; IC no.560794 & Mairong gedeba & $\begin{array}{l}\text { Mairong-Rice kernel of Maijau-di-gidiba (tall plant with } \\
\text { long panicle); Gedeba-large. }\end{array}$ & Oryza sativa L. [Poaceae] \\
\hline 8. & PM-824 & Hamlai gimindi & Hamlai-the plant; gimindi-ripe & $\begin{array}{l}\text { Emblica officinalis Gaertn. } \\
\text { [Euphorbiaceae] }\end{array}$ \\
\hline 9. & PM-825; IC no.560794 & Maireng gedeba & $\begin{array}{l}\text { Maireng- Rice kernel of Maijau-di-gidiba (tall plant with } \\
\text { long panicle); Gedeba-large. }\end{array}$ & Oryza sativa L. [Poaceae] \\
\hline 11. & PM-826 & Mairong praisong & Mairong-Rice kernel & Oryza sativa L. [Poaceae] \\
\hline 13. & PM-827; IC no.560793 & Banglaima kasiba & $\begin{array}{l}\text { Banglaima-A Jhum cultivar rice landrace Banglaisha; } \\
\text { kasiba-small. }\end{array}$ & Oryza sativa L. [Poaceae] \\
\hline 14. & PM-828; IC no.560794 & Mairong gedeba & $\begin{array}{l}\text { Maireng- Rice kernel of Maijau-di-gidiba (tall plant with } \\
\text { long panicle); Gedeba-large. }\end{array}$ & Oryza sativa L. [Poaceae] \\
\hline 16. & PM-829; IC no.560794 & Maireng gedeba & $\begin{array}{l}\text { Maireng- Rice kernel of Maijau-di-gidiba (tall plant with } \\
\text { long panicle); Gedeba-large. }\end{array}$ & Oryza sativa L. [Poaceae] \\
\hline 18. & PM-830 & Mairong daoga jairungdi & $\begin{array}{l}\text { Mairong-Rice kernel; daoga Jairungdi- rice cleaning } \\
\text { expert. }\end{array}$ & Oryza sativa L. [Poaceae] \\
\hline 19. & PM-831; IC no.560797 & Mairongma gedeba & $\begin{array}{l}\text { Mairongma- Rice kernel of Maiju-walao-gidiba (sticky } \\
\text { and with mild aroma); Gedeba- large. }\end{array}$ & Oryza sativa L. [Poaceae] \\
\hline 20. & PM-832; IC no.560794 & Mairong gedeba & $\begin{array}{l}\text { Maireng- Rice kernel of Maijau-di-gidiba (tall plant with } \\
\text { long panicle); Gedeba-large. }\end{array}$ & Oryza sativa L. [Poaceae] \\
\hline
\end{tabular}


Table 4. Continued.

\begin{tabular}{|c|c|c|c|c|}
\hline 21. & PM-833; IC no. 560803 & Mairong kasiba & $\begin{array}{l}\text { Mairong-Rice kernel of Maiyen-maiju (a wet cultivar); } \\
\text { kasiba-small. }\end{array}$ & Oryza sativa L. [Poaceae] \\
\hline 22. & PM-834; IC no.560797 & Mairongma gedeba & $\begin{array}{l}\text { Mairongma-large Rice kernel of Maiju-walao-gidiba } \\
\text { (sticky and mild with aroma); Gedeba-large. }\end{array}$ & Oryza sativa L. [Poaceae] \\
\hline 23. & PM-835; IC no.560794 & Mairong gedeba & $\begin{array}{l}\text { Mairong- Rice kernel of Maijau-di-gidiba (with tall plant } \\
\text { and long panicle); Gedeba-large. }\end{array}$ & Oryza sativa L. [Poaceae] \\
\hline 26. & PM-836; IC no.560793 & Banglaima & Banglaima-A Jhum cultivar rice landrace Banglaisha. & Oryza sativa L. [Poaceae] \\
\hline 27. & PM-837; IC no.560804 & Maireng & Maireng-Rice kernel of Dimri-maisa (a late variety). & Oryza sativa L. [Poaceae] \\
\hline 29. & PM-838; IC no. 560803 & Mairong kasiba & $\begin{array}{l}\text { Mairong-Rice kernel of Maiyen-maiju (a wet cultivar); } \\
\text { kasiba-small. }\end{array}$ & Oryza sativa L. [Poaceae] \\
\hline 30. & PM-839; IC no. 560803 & Mairong & Mairong-Rice kernel of Maiyen-maiju (a wet cultivar). & Oryza sativa L. [Poaceae] \\
\hline 31. & PM-840; IC no.560793 & Banglaima kasiba & $\begin{array}{l}\text { Banglaima-A Jhum cultivar rice landrace Banglaisha; } \\
\text { kasiba-small. }\end{array}$ & Oryza sativa L. [Poaceae] \\
\hline 32. & PM-841; IC no. 560803 & Mairong kasiba & $\begin{array}{l}\text { Mairong-Rice kernel of Maiyen-maiju (a wet cultivar); } \\
\text { kasiba-small. }\end{array}$ & Oryza sativa L. [Poaceae] \\
\hline 34. & PM-842; IC no.560804 & Maireng kasiba & $\begin{array}{l}\text { Maireng-Rice kernel of Dimri-maisa (a late variety); } \\
\text { kasiba-small. }\end{array}$ & Oryza sativa L. [Poaceae] \\
\hline 35. & PM-843; IC no.560804 & Mairengma & Maireng-Rice kernel of Dimri-maisa (a late variety). & Oryza sativa L. [Poaceae] \\
\hline 36. & PM-844; IC no.560804 & Maireng kasiba & $\begin{array}{l}\text { Maireng-Rice kernel of Dimri-maisa (a late variety); } \\
\text { kasiba-small. }\end{array}$ & Oryza sativa L. [Poaceae] \\
\hline 39. & PM-845; IC no.560804 & Maireng & Maireng-Rice kernel of Dimri-maisa (a late variety). & Oryza sativa L. [Poaceae] \\
\hline 40. & PM-846; IC no.560804 & Maireng kasiba & $\begin{array}{l}\text { Maireng-Rice kernel of Dimri-maisa (a late variety); } \\
\text { kasiba-small. }\end{array}$ & Oryza sativa L. [Poaceae] \\
\hline 41. & PM-847 & Kimbersi & Kim-Kimdaula plant; ber- flower & Gloriosa superba L. [Liliaceae] \\
\hline 42. & PM-848 & Birengsa & $\begin{array}{l}\text { Biring maisa-A fine sticky rice landrace, used for } \\
\text { traditional beer Biron-judima preparation. }\end{array}$ & Oryza sativa L. [Poaceae] \\
\hline
\end{tabular}




\section{REFERENCES}

Anonymous (2005). Souvenir. The $44^{\text {th }}$ General Conference cum Golden Jubilee Celebration of the Dimasa Students' Union, Maibang, N.C. hills, Assam, India, pp. 74-76.

Ashalata DK, Khan ML, Tripathy RS (2005). Ethnomedicinal plants in the sacred groves of Manipur. Indian J. Trad. Knowl. 4(1):21-32.

Barpujari SK (1997). History of the Dimasas (From the earliest times to 1896 A.D.). N. C. Hills Autonomous Council publ., Haflong, Assam, India, p. 220.

Bhatla N, Mukherjee T, Singh G (1984). Plants:Traditional worshiping. Indian J. Hist. Sci. 19(1):37-42.

Bor NL (1942a). Some remarks upon the geology and flora of the Naga and Khasi hills.150 ${ }^{\text {th }}$ Ann Vol. Roy. Bot. Gard. Calcutta, pp. 129-135.

Bor NL (1942b). The relict vegetation of the Shillong Plateau. Botanical Survey of India, Howrah, India.

Chauhan AS, Singh KP, Singh DK (1996). A contribution to the Flora of Namdapha, Arunachal Pradesh. BSI, Calcutta.

Darlong VT (1995). Wildlife preservation and community action. In Tiwari BK and Singh S (Eds.) Conservation of degraded hills. Kushal Publ. Shillong pp. 147-159.

Davis SH (1993). Indigenous views of Land and Environment. The World Bank, Washington.

Deb DB (1981). The flora of Tripura State, Vol. I and II. Today and Tomorrow's Publ., New Delhi.

Deeney J, Fernandes W (1992). Tribal dependence and tradition on Forests. In: Fernandes W (ed.) Nation. Dev. and Tribal Deprivation, Indian Social Inst., Delhi.

Godbole A (1996). Role of Tribals in preservation of Sacred Forests. In SK Jain (ed.), EHW, Deep publ., New Delhi. pp. 345-348.

Gogoi P, Borthakur SK (1991). Plants in religio-cultural beliefs of the Tai Khamtis of Assam (India). Ethnobotany 3:89-95.

Guha UC (1912). Cacharer Itibritta, (Original Bangla version). pp. 105106.

Hajra PK (1975). Law Lyngdoh (Sacred Grove), Meghalaya. Government of Meghalaya, Shillong, India.

Haridasan K, Rao RR (1985, 1987). Forest Flora of Meghalaya. Vol. 2 Bishen Singh Mahendra Pal Singh, Dehra Dun, India.

Jain AK (1988). Tribal clans in central India and their role in conservation. J. Environ. Conserv. 15:368.

Jain SK (1989). Ethnobotanical aspects of Tropical Ecosystems. Proc. $9^{\text {th }}$ Intern. Symp. Trop. Ecol. Varanasi, India.

Jain SK, Rao RR (1977). A handbook of field and herbarium methods. Today and Tomorrow, Printers and Publishers, New Delhi, India, pp. 33-58.

Kanjilal UC, Das A, Kanjilal PC, De RN (1934-1940). Flora of Assam, Vol. 1-5. Govt. of Assam, Shillong (Vol. 5 by Bor NL). (Reprinted 1982)

Khiewtam RS, Ramakrisnan PS (1989). Socio-cultural studies of the sacred groves of Cherrapunjee and adjoining areas in northeastern India. Man India 69:64-71.

Kulkarni DK, Upadhye A, Kumbhoskar MS (1996). Religious forest patches among Mahadeo Koli tribal localities- Social, Cultural and Environmental Relationship. In S K Jain (ed.), EHW, Deep Publ., New Delhi, pp. 349-351.

Lalsim R (2005). Tribes of N. C. Hills, Assam. N. C. Hills Autonomous Council publ., $1^{\text {st }}$ edition, Assam, India, p. 263.

Lebbie AR, Guries RP (1995). Ethnobotanical value and conservation of Sacred Groves of the Kpaamende in Sierra Leone. Econ. Bot. 49(3):297-308.
Nipunage DS, Vartak VD, Kumbhoskar MS (1992). Cultural heritage of Sacred groves. Proc. Of South Indian Hist. Cong., Pune. pp. 170176.

Nunisa LK (2006). A handbook of Dimasa customary practices. N. C. Hills Autonomous Council Publication, Haflong, Assam, India, p. 132.

Ramakrisnan PS (1985). Tribal man in the humid tropics of the NorthEast. Man India 65:1-32.

Ramakrisnan PS (2000a). Sacred Mountain forests and Biodiversity. In, Price MF and Butt $\mathrm{N}$ (ed.): Forests in Sustainable Mountain Development: A state of Knowledge Report for 2000, CABI Publ., Wallingford, UK, pp. 117-126.

Ramakrisnan PS (2001). Ecology and Sustainable Development. National Book, Trust, India, 1st edition, p. 198.

Ramakrisnan PS, Kiewtam RS (1989). Socio-cultural studies of the Sacred Groves at Cherrapunji and Adjoining areas in North-eastern India. Man India 69:64-71.

Ramakrisnan PS, Saxena KG, Chandrasekhara UM (1998). Conserving the Sacred: For Biodiversity management. UNESCO, Oxford and IBH publishers, New Delhi.

Rao RR (1996). Indigenous People and Forests: Perspective of an Ethnobotanical study from Nagaland, North-east India. In S.K. Jain (ed.), EHW, Deep Publishers, New Delhi, pp. 367-371.

Rodriguez-Navarro GE (2000).Case Study: Sacred Forests in Sierra Nevada de Santa Marta Columbia. In, Price M F and Butt N (eds.): Forests in Sustainable Mountain Development: A state of Knowledge Report 2000, CABI Publ., Wallingford, UK, pp. 28-130.

Rowntree JE (1953). An introduction to the vegetation of the Assam Valley. Indian For. Rec. (n. s.) 9(1):1-87.

Sharma GD (2000). Minimal descriptors (for characterization and evaluation) of agri-horticultural crops (part-I). Nat. Bur. Plant Gen. Resour., New Delhi, India.

Shukla GP, Haridarshan K (1996). Ethnoforestry, its relevance in Arunachal Pradesh. Arunachal For. News, India 14(2):20-24.

Singh NP, Singh KP, Singh DK (Eds.) (2002). Flora of Mizoram: Vol. I: Ranunculaceae-Asteraceae. BSI, Calcutta.

Tiwari BK, Barik SK, Tripathi RS (1995). Sacred groves of Meghalaya: status and strategies for their conservation. NEHU, Shillong, India.

Tiwari BK, Barik SK, Tripathi RS (1998). Biodiversity value, status and strategies for conservation of sacred groves of Meghalaya, India. Ecosyst. Health 4(1):1-13.

Vartak VD (1996). Sacred Groves for in-situ conservation. In S K Jain (ed.), EHW, Deep Publ., New Delhi. pp. 300-302.

Vartak VD, Gadgil M (1997). Studies on Sacred Groves along Western Ghats in Maharastra and Goa: Role of Believes and Folklores. In S K Jain (ed.), Contribution to Indian Ethnobot., Sci. Publ., Jodhpur, India, pp. 313-318.

Vartak VD, Kumbhoskar MS, Nipunage DS (1987). Sacred Groves of tribal areas along the Western Ghats: Treasure trove of medicinal plants. Bull. Medicoethnobot. Res. 8(1-2):77-84.

Wells M, Brandon K (1992). People and parks, linking protected area management with local communities. The World Bank, Washington. 